\title{
A new titanosaur sauropod dinosaur from the Upper Cretaceous of North Patagonia, Argentina
}

Leonardo S. Filippi, Rodolfo A. García, and Alberto C. Garrido

Acta Palaeontologica Polonica 56 (3), 2011: 505-520 doi: http://dx.doi.org/10.4202/app.2010.0019

A new sauropod titanosaur from the Upper Cretaceous Anacleto Formation is described.

Narambuenatitan palomoi gen. et sp. nov., is diagnosed by cranial and axial

autapomorphies. The holotype, which represent a subadult individual, consists of the

left premaxilla and maxilla, braincase, both quadrates, one cervical vertebrae, one dorsal vertebra, fragments of cervical and dorsal ribs, seventeen caudal vertebrae, caudal transverse processes, fragments of haemal arches, left sternal plate, right coracoid, left humerus, left ulnae, both pubes, iliac pedicel, proximal fragment of right ischia, and an incomplete left femur. The phylogenetic analysis indicates that Narambuenatitan is a non-eutitanosaurian lithostrotian, and that it shares with Epachthosaurus a neural spine in middle caudal vertebrae which are laminar and posteriorly elongated.

Key words: Sauropoda, Titanosauria, phylogeny, Campanian, Cretaceous, Anacleto Formation, Neuquén Basin, Argentina.

Leonardo S. Filippi [1sfilippi@yahoo.com.ar], Museo “Carmen Funes”, Av. Córdoba 55, (8318) Plaza Huincul, Neuquén, Argentina; Rodolfo García [rgarcia@uncoma.edu.ar ], Inibioma - Museo de Geología y Paleontología, Universidad Nacional del Comahue, Buenos Aires 1400, (8300) Neuquén, Argentina; Alberto C. Garrido [algene@ copelnet.com.ar], Museo Provincial “Prof. Dr. Juan Olsacher”. Dirección General de Minería, Elena de Vega 472, (8340) Zapala, Neuquén, Argentina.

This is an open-access article distributed under the terms of the Creative Commons Attribution License (for details please see creativecommons.org), which permits unrestricted use, distribution, and reproduction in any medium, provided the original author and source are credited. 
Fof Full text $(1,131.0 \mathrm{kB})$ 